\title{
Coccolithophorids in Polar Waters: Wigwamma spp. Revisited
}

\author{
Helge A. THOMSEN ${ }^{1}$, Jette B. ØSTERGAARD ${ }^{2}$ and Mikal HELDAL ${ }^{3}$ \\ ${ }^{1}$ National Institute of Aquatic Resources, Technical University of Denmark, Charlottenlund, Denmark; ${ }^{2}$ Nørrebrogade $52 a 5^{\text {th }}$, \\ 2200 Copenhagen N, Denmark; ${ }^{3}$ Dep. of Biology, Thormøhlensgate 53, 5020 Bergen, Norway
}

\begin{abstract}
A contingent of weakly calcified coccolithophorid genera and species were described from polar regions almost 40 years ago. In the interim period a few additional findings have been reported enlarging the realm of some of the species. The genus Wigwamma is revisited here with the purpose of providing, based on additional sampling from both polar regions, an update on species morphology, life history events and biogeography that can serve as a reference for the future. A new genus, Pseudowigwamma gen. nov. is described to accommodate Wigwamma scenozonion, a species which critically deviates from a core group of five Wigwamma species in terms of coccolith morphology and life history events. Wigwamma armatura sp. nov. is described on the basis of material from the Weddell Sea, Antarctica. While fitting nicely into the Wigwamma generic concept, the species adds new dimensions to the overall appearance of the coccolith armour of the cell.
\end{abstract}

Key words: Coccolithophorid, Wigwamma, W. armatura sp. nov., Pseudowigwamma gen. nov., polar regions, electron microscopy.

Abbreviations: TEM - transmission electron microscope; SEM - scanning electron microscope; LM - light microscope; AMERIEZ, EPOS, ANT X/3 - acronyms for Antarctic cruises (see Materials and Methods); NEW, NOW - acronyms for Arctic cruises (see Materials and Methods)

\section{INTRODUCTION}

Haptophyte algae (Prymnesiophyceae) are known to be a significant component of marine phytoplankton in lower latitude regions of the world's oceans. Results from e.g. Pacific Ocean surveys indicate (Thomsen et al. 1994) that the biomass and relative contribution of haptophytes to autotrophic biomass is relatively constant $(13 \pm 9 \%)$ over a wide variety of environmental settings. Cell abundances typically fluctuate around $10^{6}$ cells $1^{-1}$

Address for correspondence: Helge A. Thomsen, DTU Aqua, Jægersborg Allé 1, 2920 Charlottenlund, Denmark; Fax: +45 3588 3333; E-mail: hat@aqua.dtu.dk when considering the unmineralized and weakly calcified haptophytes, whereas fully mineralized coccolithophorids typically abound to $10^{3}-10^{5}$ cells $1^{-1}$.

Haptophytes at large remain a significant component when entering polar waters which are characterized by low and relatively invariant temperatures $\left(-2\right.$ to $\left.+5^{\circ} \mathrm{C}\right)$, and extreme variation in irradiance and daylength. The seasonal ice cover of these waters also contributes to the prolonged periods of low light conditions and has in general a year round profound impact on the living conditions of all marine life in these waters. Fairly dramatic changes are, however, evident with regard to species diversity when approaching high latitude waters. The genus Phaeocystis is from a biomass perspective 
the key haptophyte taxon in these waters, whereas it is obvious that species abundance and diversity is declining when considering other unmineralized haptophyte taxa, e.g. Chrysochromulina spp. Fully mineralized coccolithophorid species are virtually absent from high latitude polar waters (e.g. Charalampopoulou et al. 2011, Findlay and Giraudeau 2000).

A contingent of weakly mineralized coccolithophorid species referred to the genera Papposphaera Tangen 1972, Pappomonas Manton and Oates 1975, Turrisphaera Manton, Sutherland and Oates 1976, Wigwamma Manton, Sutherland and Oates 1977, Calciarcus Manton, Sutherland and Oates 1977, and Trigonaspis Thomsen 1980a, has been shown to be consistently present in polar waters (e.g. Manton and Oates 1975; Manton and Sutherland 1975; Manton et al. 1976a, b; Manton et al. 1977; Thomsen 1980a, b, c, d; Thomsen 1981; Thomsen et al. 1988). It should be emphasized that the taxa described in the above cited papers form a recurrent and characteristic, however not in all cases endemic, element of polar nanoplankton. Whereas the typical haptophyte alga is photosynthetic, the polar weakly calcified taxa are without chloroplasts and appear to be heterotrophs that scavenge bacteria and other small sized particles (Marchant and Thomsen 1994, Masanobu Kawachi, pers. com.). The documentation for the aplastidic condition stems so far from light microscopy of live and fixed material using e.g. epifluorescence techniques. Many haptophyte taxa are known to be mixotrophic. It therefore appears likely that the absence of a chloroplast should be considered a secondary loss and the switch to heterotrophy an adaptation to life in prolonged seasonal darkness.

The coccolithophorid life cycle typically consists of an alternation of a diploid, motile phase bearing heterococcoliths and a haploid, motile phase which produces holococcoliths (Billard 1994, Cros et al. 2000, Houdan et al. 2004). Each phase has the ability to reproduce asexually for an extended period of time. It is incompletely known what triggers the transition from one phase to the other and what selective benefits these organisms gain from maintaining an alternation of haploid and diploid phases in their life cycle. While it is obvious that diploidy has an immediate advantage for the organism in a variety of genetic aspects, e.g. buffering against deleterious mutations, it has been hypothesized (e.g. Lewis 1985, Valero et al. 1992) that the advantage of haploidy can confer significant ecological advantages to the cell in particular when confronted with a nutrient scarce habitat. A reduction in cell size of the haploid cell in comparison with its diploid counterpart improves its nutrient uptake potential, and there is additionally a direct saving of essential nutrients coupled to the reduction of the DNA inventory. Houdan et al. (2006) has provided experimental evidence in favour of the nutrient scarcity hypothesis. A strong UV backscattering has been linked to the crystalline photonic structure of certain holococcoliths (Quintero-Torres et al. 2006). This phenomenon might provide the holococcolith bearing haploid stage with additional competitive advantages when populating the surface waters of a nutrient depleted stratified water mass. Noël et al. (2004) managed to experimentally induce an alternation of the holococcolithophorid and heterococcolithophorid phases of Calyptrosphaera sphaeroidea Schiller. An extrapolation from their laboratory experiments indicates that the phase regulation is based on changes between pelagic and coastal environments, coupled with changes in seasonal conditions (e.g. light regime and temperature).

Evidence has accumulated (Thomsen et al. 1991) in favour of also linking the above mentioned polar genera into consistent hetero-/holococcolithophorid pairs, i.e. Papposphaera-Turrisphaera, Pappomonas-Trigonaspis, and Wigwamma-Calciarcus. This obviously has profound impact on basic nomenclature within the group and how to handle practical issues related to transparent cross referencing to earlier observations. Realizing that we are still at an early stage with regard to unraveling the complete pattern of such cross-generic relationships we will in most cases in this and subsequent papers take a pragmatic approach and utilize the genus name and species epithet under which the taxon in question was originally described. Once life history stages and the unique combinations of species have been unequivocally established, a single formal name should be selected based on normal taxonomic rules and principles, and applied to both phases of a life-cycle (Thomsen et al. 1991, Cros et al. 2000, Young et al. 2003). Once this is achieved it is further suggested (Young et al. 2003) that whenever needed for the purpose of a precise recording of findings the life history phase can be stated be adding HET (heterococcolith) or HOL (holococcolith) to the species name.

We are currently preparing a series of papers that will in turn provide an update with regard to species diversity, life history events etc. with reference to each of the weakly calcified polar coccolithophorid genera. The current paper provides an overview of the genus Wigwamma, incl. the description of Wigwamma arma- 
tura sp. nov., and Pseudowigwamma gen. nov. (based on $W$. scenozonion). Circumstantial evidence exists in favour of linking species of Wigwamma with species of Calciarcus in a shared life cycle (Thomsen et al. 1991). The current status with regard to species diversity within Calciarcus will be covered in a subsequent paper (Thomsen and Østergaard 2014).

\section{MATERIALS AND METHODS}

For the purpose of this paper we have, with regard to the Southern Ocean, considered material sampled from south of the Antarctic Convergence and, in the northern hemisphere, the Arctic Ocean and its surrounding ice-covered seas.

The Antarctic material originates from the R/V 'Polarstern' ANT VII/3 'EPOS II' cruise (Nov. 1988-Jan. 1989) and the R/V 'Polarstern' ANT X/3 'Herbst im Eis' cruise (April-May 1992), with both cruises occupying stations in the Weddell Sea region (Fig. 1).

The Arctic material originates from the R/V 'Polarstern' ARK IX/3 North-East Water Polynya (NEW) cruise June-July 1993 and the R/V 'Pierre Radisson' North Water Polynya cruise (NOW) April-May 1998 (Fig. 2). The term 'polynya' refers to an area of open water surrounded by sea ice. A polynya can be formed by the presence of a heat source that keeps the area from freezing, but the formation process may also involve wind or ocean currents that carry ice away from the polynya. Additional northern hemisphere sampling took place at the University of Copenhagen Arctic Station (Disko Bay, West Greenland) during the summers of 1988, 1990 and 1994 (Fig. 2) and from the Rijpfjorden, Svalbard (Fig. 2), during 2012.

The protocol for processing water samples for transmission electron microscopy (TEM) and light microscopy (LM) were similar on all sampling occasions (see Moestrup and Thomsen 1980). The nanoplankton community was concentrated for further processing by means of either centrifugation of a prefiltered (usually $20 \mu \mathrm{m}$ ) water sample or centrifugation of prefiltered material resuspended from an initial filtration of cells on top of e.g. a $1 \mu \mathrm{m}$ nucleopore filter. Small droplets of cells from the resuspended final pellet of material were - irrespective of the initial concentration procedure - placed on either carbon coated grids for TEM or rinsed coverslips for LM. Cells were subsequently fixed in the vapour from a $1-2 \%$ solution of $\mathrm{OsO}_{4}$. After drying both grids and coverslips were carefully rinsed in distilled water in order to remove salt crystals. Grids were shadow cast with either $\mathrm{Au} / \mathrm{Pd}$ of $\mathrm{Cr}$ prior to the examination in JEOL electron microscopes property of the Botanical Institute at the Univ. of Copenhagen. Coverslips intended for LM were air mounted upside down in order to render possible the use of a $\times 100$ objective (see Thomsen 1982). Material for SEM (Svalbard, see Fig. 25) was prepared by gentle filtration of a water sample on top of a $1 \mu \mathrm{m}$ nucleopore filter. The formation of salt crystals that might obstruct the visibility of cells was minimized by allowing the pumping system to almost completely dry out the filter. Filters were sputter coated with gold and examined on a Zeiss Supra 55VP scanning electron microscope at the Bergen University Laboratory for Electron Microscopy.
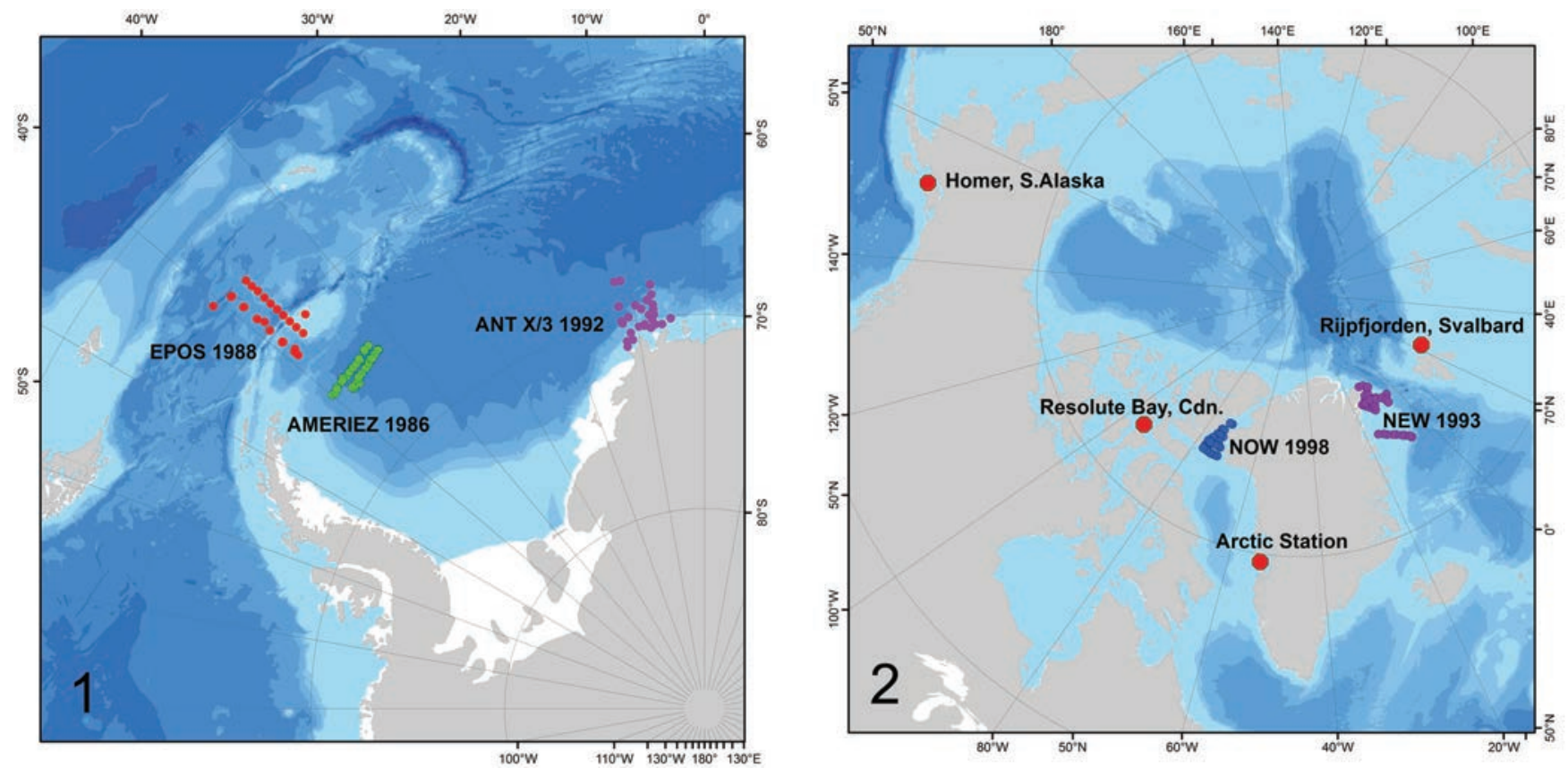

Figs 1-2. Collection sites. 1 - map of the Weddell Sea, Antarctica, indicating sampling sites during three cruises; 2 - map of the Arctic showing the location of sampling sites where species of Wigwamma and Pseudowigwamma have been recorded. 


\section{RESULTS AND INTERPRETATION}

\section{Wigwamma Manton, Sutherland and Oates 1977}

The genus Wigwamma comprises approximately $5 \mu \mathrm{m}$ sized nanoflagellates with two flagella and a somewhat shorter haptonema. The cell surface is covered by two layers of different-sized organic scales. The inner layer (see e.g. Figs 16, 38) consists of small rimless scales with a patterning consisting of both radial elements and arcs of circular threads with focal points differing from the geometrical centre of the scale (Manton et al. 1977). The somewhat larger scales forming the exterior layer has a similar plate patterning but is additionally calcified along the rim (narrow-rimmed muroliths) and with all or some circum-flagellar scales carrying a superstructure of rod-shaped crystallites converging to a single point distally. The rim calcification typically consists of two tiers of differently sized rectangular crystallites.

The genus currently comprises 5 species: $W$. arctica Manton, Sutherland and Oates 1977 (type species), W. annulifera Manton, Sutherland and Oates 1977, W. antarctica Thomsen in Thomsen et al. 1988, W. triradiata Thomsen in Thomsen et al. 1988, and the somewhat enigmatic W. scenozonion Thomsen 1980 that is here transferred to Pseudowigwamma gen. nov. (see below). A sixth species, W. armatura sp. nov., is described below based on material from Antarctica. Biogeographical details of all taxa are accounted for in Table 2.

The small narrow-rimmed muroliths which is characteristic feature of species of Wigwamma suggest affinity with the Papposphaeraceae Jordan and Young 1990. The genus is treated under the heading 'genera incertae sedis aff. Papposphaeraceae' in Young et al. (2003).

\section{Wigwamma arctica Manton, Sutherland and Oates 1977}

The $W$. arctica coccoliths are monomorphic although in some specimens examined (e.g. Figs 10, 12) it is evident that the coccoliths clustered at the flagellar pole are larger than other coccoliths (varimorphic). The most conspicuous feature of the coccolith is the tent-like superstructure composed of four converging rods which arise from the calcified scale rim. The type material from West Greenland (Manton et al. 1977; loc. cit. Fig. 7) is characterized by rods arising from slightly enlarged rim crystallites and also by the fact that the four rods are exactly equal in length and fuse apically at the very same point. Sampling of additional material from West Greenland (Thomsen 1981) consistently reveals coccoliths of $W$. arctica that exactly mirrors those of the type material. However, coccoliths like those illustrated in Fig. 4 are also frequently observed. In these the rim crystallites that support the rods are significantly enlarged giving the coccolith a pentagonal outline in side view.

Examination of material from a range of polar habitats has revealed additional variability in details of the morphology of individual calcified elements and in the assembly of these. Variation encountered in material from the Antarctic encompasses coccoliths (Thomsen et al. 1988 and Figs 3, 5) in which the four rods meet at a single point apically, but attach to rim crystallites that do not deviate morphologically from neighbouring crystallites. A typical feature of many W. arctica cells encountered in e.g. Antarctic 'EPOS' samples is the extension of a single rod above the point of union of the remaining three rods (Figs 6, 10). The overall consistency and homogeneity of this phenomenon rules out the possibility that the protruding tips can be considered preparational artefacts involving distortion of a single element of a 'wigwam'. In the vast majority of cells examined displaying coccolith tip extensions this feature is coupled with the presence of proliferated rim crystals that support the converging rods of the superstructure. The possible taxonomic significance of the morphological variability encountered, i.e. presence or absence of enlarged supporting rim crystals and presence or absence of a protruding tip from a single rod, is eliminated when examining the rare Antarctic (EPOS) individual (Figs 9, 11) that combines the two basic types of coccoliths, i.e. coccoliths with struts that adjoin at a single point and without proliferation of the supporting rim

\footnotetext{
Figs 3-8. Wigwamma arctica TEM (Figs 3-6) and LM (Figs 7-8) whole mounts. 3 - complete cell (Antarctica / EPOS) showing flagella and haptonema; $\mathbf{4}$ - single coccoliths with proliferated rim crystallites supporting the superstructure (Arctic Station); 5 - detail of coccoliths without enlarged supporting rim crystallites; notice the organic base plate meshwork (Antarctica / AMERIEZ); 6 - cluster of coccoliths with superstructure extensions distally and enlarged widened crystallites that support the superstructure (Antarctica / EPOS); 7-8 - the 'wigwams' are clearly visible in whole cell preparations for LM when examined using Nomarski optics (Antarctica / EPOS).
} 
Coccolithophorids - Wigwamma revisited 241

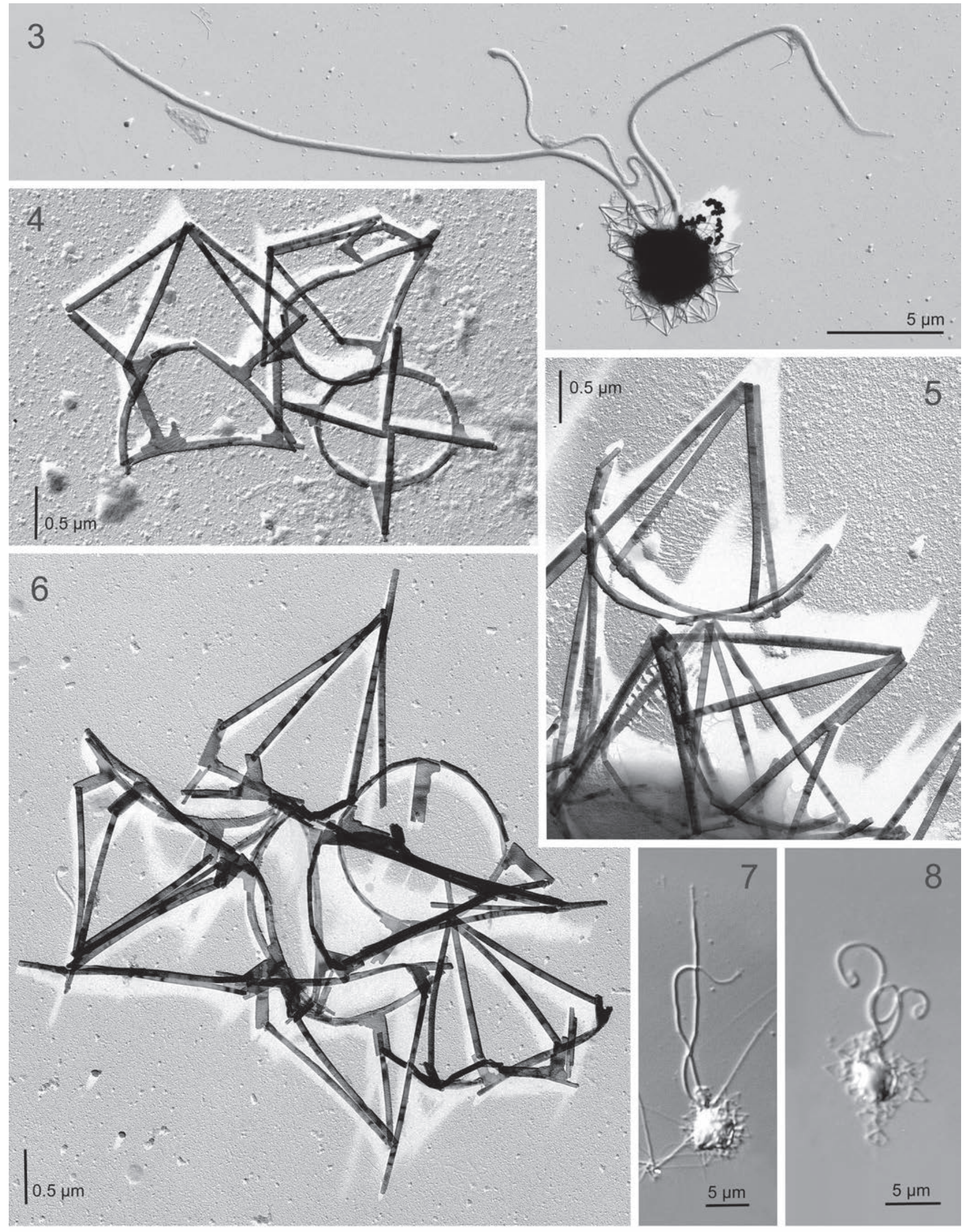


crystals (Figs 9, 11 arrows) and other coccoliths that display a protruding single rod and proliferated supporting rim crystals (Figs 9, 11 arrowheads).

High arctic material of $W$. arctica from the North East Water polynya comprises cells (Fig. 12) that are basically identical to the West Greenland type material. However, other cells from the same water mass (Fig. 14) mirror Antarctic material with regard to the anterior protrusion of a single rod which in this particular case is morphologically distinct from the remaining three rods by having a sharp pointed tip (Fig. 14 and inset). In these coccoliths the rods attach to scale crystallites that are not morphologically deviant from those forming the remaining part of the rim calcification.

The coccolith variability accounted for above and in Figs $3-14$ is summarized in Table 1.

The overall conclusion is that $W$. arctica is most adequately dealt with as a taxon that is characterized by coccoliths of one type (with the occasional apicalantapical size differences), a scale rim calcification that consists of two tiers of crystallites and a tent-like superstructure with a fourfold symmetry. Superstructure attachment and termination is variable. When scrutinizing the additional morphological variability tabulated below no clear cut picture emerges that could support e.g. a separation of material from either of the poles. Wigwamma arctica must be interpreted and dealt with as a taxon characterized by extensive morphological plasticity.

\section{W. triradiata Thomsen in Thomsen et al. 1988}

The original description of this taxon (Thomsen et al. 1988) was based on only two specimens from the Weddell Sea (AMERIEZ cruise). Subsequent collection of material from Antarctic waters has documented that this taxon is consistently present and allows for a reanalysis of details of coccolith morphology.

W. triradiata is a dimorphic species with a ring of larger circum-flagellar coccoliths that differ markedly from those that cover the remaining part of the cell body (Figs 15, 19). All coccoliths display a base plate calcification that consists of two tiers of crystallites (Fig. 17), with narrow rods forming a proximal layer which is superimposed by a distal ring comprised of larger rectangular crystallites. All coccolith base plates appear to be of approximately the same size, ca. $0.7 \times 1 \mu \mathrm{m}$. The flagellar pole coccoliths range in height from 1.3 to $2.0 \mu \mathrm{m}$. Despite the very large number of specimens available for scrutinizing the exact configuration of the superstructure is not fully elucidated. The superstructure appears to consist of four rods arranged in pairs that attach individually to much enlarged neighbouring crystals from the distal scale rim tier (Fig. 17). One rod from each pair is fairly narrow, whereas accompanying

Table 1. A summary of coccolith superstructure morphological plasticity within W. arctica.

\begin{tabular}{|c|c|c|c|}
\hline Superstructure & $\begin{array}{l}\text { Rim crystallite } \\
\text { (point of rod attachment) }\end{array}$ & Antarctic & Arctic \\
\hline \multirow[t]{2}{*}{$\begin{array}{l}\text { Rods distally united } \\
\text { at a single point }\end{array}$} & No enlargement & $\begin{array}{l}\text { AMERIEZ (Fig. 5), EPOS } \\
\text { (Figs 9, 11) and ANT X/3 material }\end{array}$ & \\
\hline & Enlargement & $\begin{array}{l}\text { AMERIEZ and EPOS (Fig. 11) } \\
\text { material }\end{array}$ & $\begin{array}{l}\text { West Greenland (type material and } \\
\text { Fig. 4) and NEW material (Fig. 12) }\end{array}$ \\
\hline \multirow{2}{*}{$\begin{array}{l}\text { One rod protruding distally } \\
\text { above the remainders }\end{array}$} & No enlargement & & NEW material (Fig. 14) \\
\hline & Enlargement & EPOS (Figs $6,9,10)$ and ANT X/3 material & \\
\hline
\end{tabular}

Figs 9-14. Wigwamma arctica TEM whole mounts. 9 - cell with a mixture of coccolith types; arrows point to coccoliths where the four rods terminate at a single point; coccoliths in which one rod protrudes above the others are marked by arrowheads (Antarctica / EPOS); 10 - complete cell; notice the coiled up haptonema and a decrease in coccolith size from the anterior towards the posterior cell end (Antarctica / EPOS); 11 - detail from Fig. 9; notice neighbouring coccoliths with deviant morphology; for further description see Fig. 9 (Antarctica / EPOS); 12 - complete cell with larger coccoliths encircling the flagellar pole; rods fuse at a single point and arise from enlarged rim crystallites (Arctic / NEW); 13 - single coccolith in polar view (Arctic / NEW); 14 - coccoliths in sideview; notice the pointed protruding tip (see also inset) and the absence of proliferated rim crystallites supporting the rods (Arctic / NEW). 
Coccolithophorids - Wigwamma revisited 243

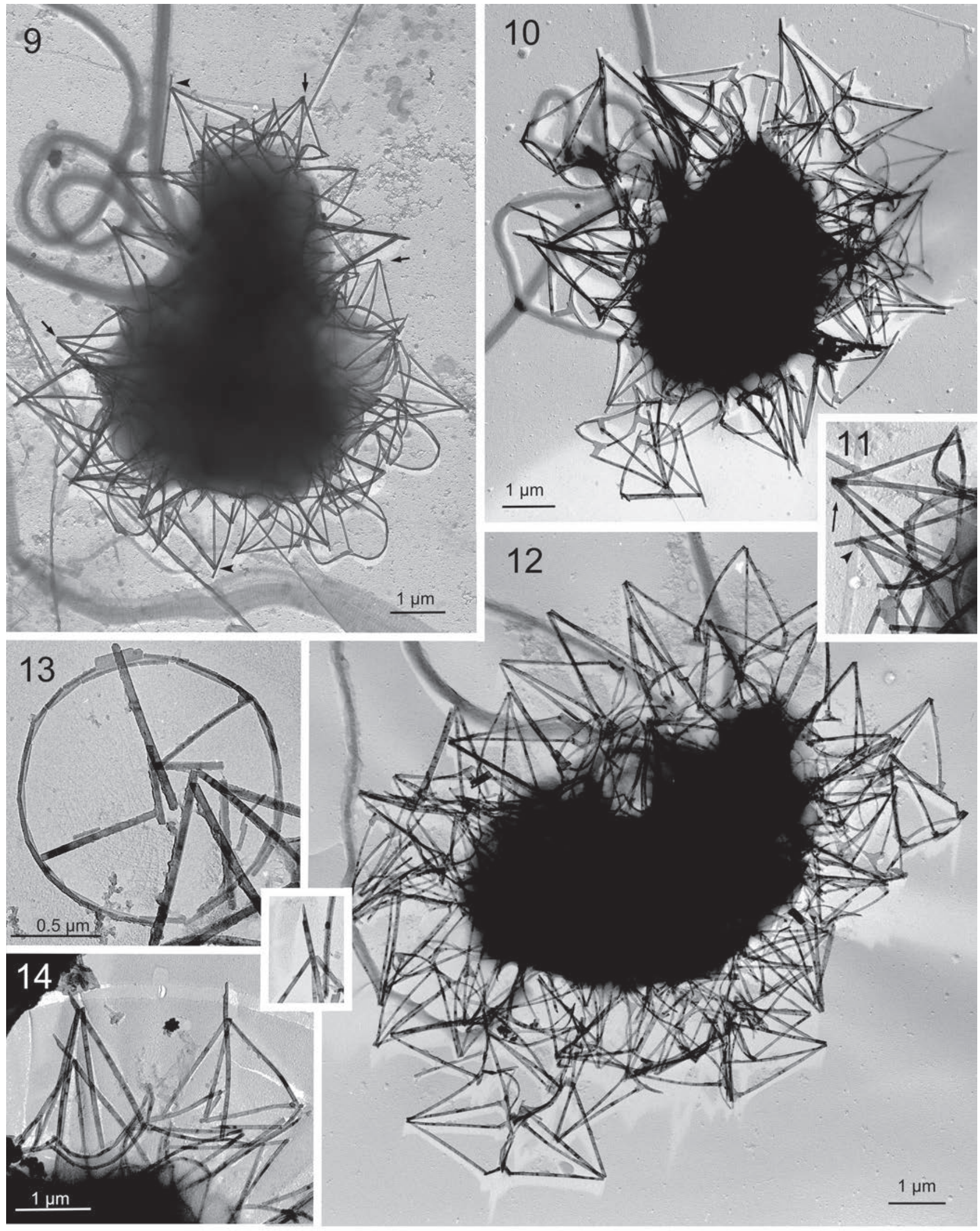


rods are wider and one of them with a characteristic attenuated tip that projects above the point of union of the remaining rods (Figs 18, 19). Whereas the difference in appearance of neighbouring rods is fairly conspicuous in Fig. 17, this is by no means always the case, see e.g. Fig. 19 where all rods appear to be quasisimilar. Body coccoliths of $W$. triradiata are characterized by a three-armed superstructure (Fig. 16) that is only slightly raised above the base plate, ca. $0.7 \mu \mathrm{m}$ (Fig. 19). Each rod attaches to enlarged rim crystallites. The linkage between rim crystallite and rod is when considering both circum-flagellar and body coccoliths facilitated by a distal notch in the subtending crystallite (Fig. 17, arrows). Non-mineralized underlayer scales (ca. 0.2 $\times 0.3 \mu \mathrm{m})$ are present and sometimes visible between coccoliths (e.g. Fig. 16, arrow).

The analysis and documentation of a large number of EPOS and ANT X/3 W. triradiata specimens has provided material (Figs 15-19) that constitutes an improved basis for future recognition of this taxon. However, it is also obvious that the abundance of cells available for study has not substantially altered the original interpretation of this taxon. Thomsen et al. (1988) states that 'it deserves mentioning that in W. triradiata the two parallel rows of rod-shaped crystallites, which make up the base-plate rim calcification, appear to be almost of the same size (like in W. arctica)'. However, this is not convincingly documented in Thomsen et al. 1988 (1.c. Fig. 20) and the access to additional material has in fact unequivocally documented that $W$. triradiata is in fact similar to e.g. W. annulifera in terms of displaying a noticeable size difference between elements of the two tiers (e.g. Fig. 17). It is further evident from scrutinizing Fig. 17 that the elements in the upper tier are offset relative to the ones in the lower tier so that they overlap like bricks. If this proves to be a general feature for species of Wigwamma it will support their affinity with genera currently allocated to the Papposphaeraceae (see Andruleit and Young 2010).

The threefold symmetry of body coccolith superstructures remains a unique feature among species of Wigwamma. The circum-flagellar coccolith superstructures display a functional bilateral symmetry which is achieved through a grouping of four rods in neighbouring pairs. In this sense and also with reference to the 'wing-like' appearance of one rod within each pair, the W. triradiata circum-flagellar coccolith superstructure can be interpreted as morphologically bridging the gap between $W$. arctica with a distinct fourfold symmetry and single rod distal projections, and W. annulifera which is characterized by a full-fledged bilateral symmetry and a dramatic hypertrophy of the wing-like element of each pair of rods (Figs 20, 25).

\section{W. annulifera Manton, Sutherland and Oates 1977}

Coccoliths of $W$. annulifera are dimorphic. Whereas coccoliths covering the major part of the cell body are of a fairly standard Wigwamma design, with the usual two tiers of crystallites forming an upright rim along the periphery of the oval, organic baseplate (Figs 22, 23), those that form a circum-flagellar rosette are very distinct in this species (Figs 20, 21). The superstructures here consist of two narrow rods that converge to a point distally (Fig. 20). Each rod emanates from an enlarged upper rim crystallite and is associated with a wing-like calcified lamina. One of the wings is typically twice as wide as the other. The narrow wing has an obliquely truncated distal end (Figs 20,21). Material of W. annulifera from either polar region appear to be morphologically very similar (see Figs 20 and 24) when examining details of the superstructures. However, a Svalbard cell examined using a scanning electron microscope reveals (Fig. 25) slightly deviating features by possessing superstructure lamina plates that are unusually large and closely appended for their entire length. It is similarly evident that the $W$. annulifera body coccoliths are virtually identical in material from both hemispheres, and also that all cells displayed (Figs 20, 24 and 25) share a distinct variability in overall size among body coccoliths from the same periplast. Smaller sized coccoliths $(0.8-1.0 \mu \mathrm{m})$ occupy the middle region of the cell, while larger coccoliths $(1.2-1.5 \mu \mathrm{m})$ occur at either end of the cell and most conspicuously so towards the anterior end of the cell. A final feature that deserves mentioning is the fact that superstructures of markedly reduced dimensions may occur at the antapical cell end (Fig. 25).

\footnotetext{
Figs 15-19. Wigwamma triradiata TEM whole mounts. 15 - complete cell with coiled up haptonema (Antarctica / EPOS); 16 - inversed printing of body coccoliths; notice (arrow) the non-mineralized under layer scales (Antarctica / ANT X/3); 17 - detail of flagellar pole and body coccolith. Notice the base ring calcification and patterning of the organic base plate, the notched interlocking (arrows) of rod and subtending crystallite and the pointed tip on one rod (Antarctica / ANT X/3); 18 - cluster of coccoliths from abandoned periplast (Antarctica / ANT X/3); 19 - detail of the cell from Fig. 15 (Antarctica / EPOS).
} 
Coccolithophorids - Wigwamma revisited 245

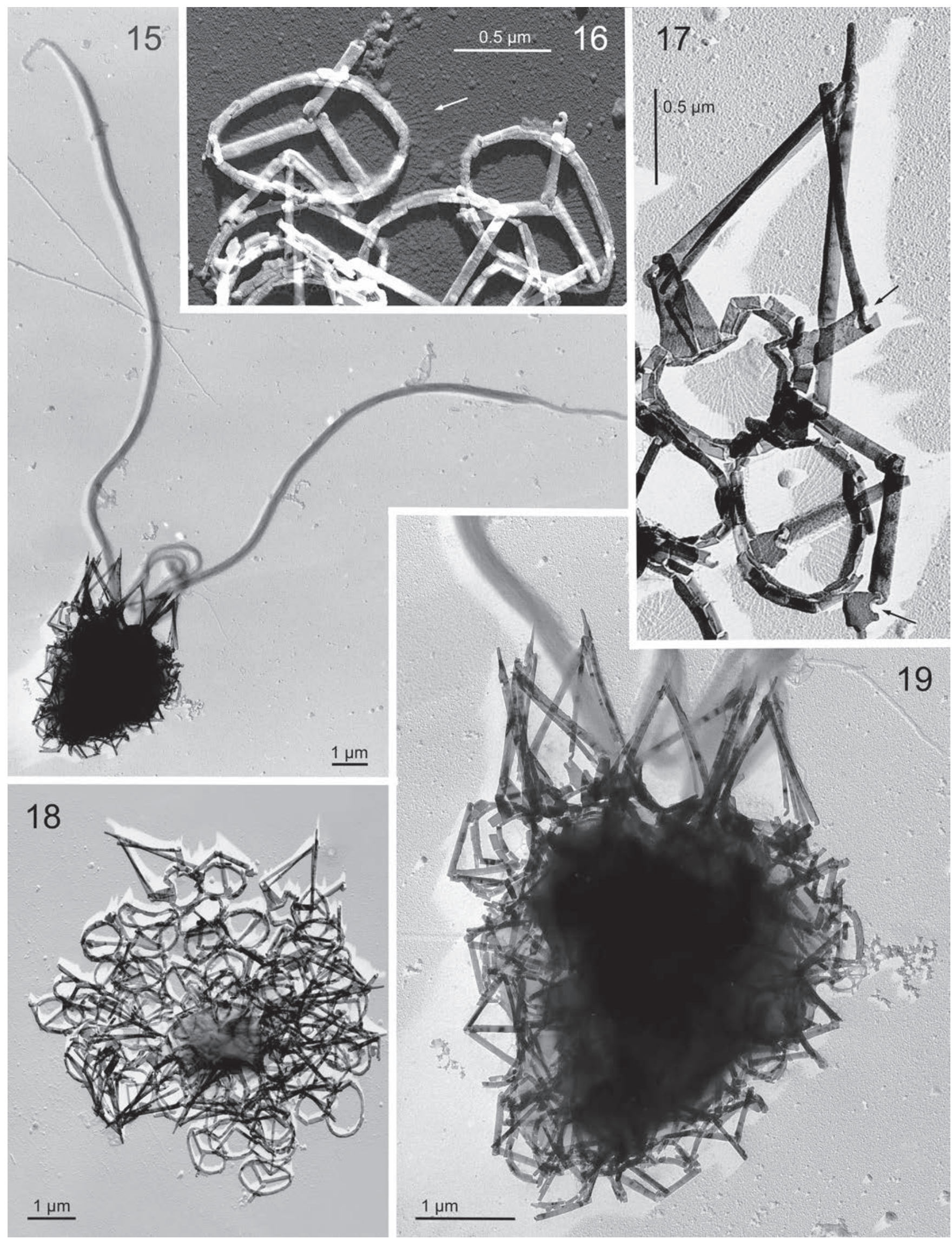


This feature is to our knowledge so far only observed in a single cell from Svalbard. However, a similar condition is observed in e.g. W. antarctica (see Thomsen et al. 1988, 1.c. Fig. 9) and is also known from a range of taxa belonging to other genera of weakly calcified polar coccolithophorids. It thus seems that the occurrence of miniaturized 'apical coccoliths' at the antapical cell end is a sporadic morphological manifestation that can hardly be assigned taxonomic significance.

\section{W. antarctica Thomsen in Thomsen et al. 1988}

The material from the EPOS and ANTX3 cruises to Antarctica (Figs 26-31) corroborates in all details the observations provided in the original species description (Thomsen et al. 1988). The W. antarctica coccoliths are of two discrete types. The scale rim calcification consists in all coccoliths of an upright rim formed by two tiers of crystallites (rod shaped proximally versus distally more rectangular, see Figs 29, 30). A coccolith superstructure is a characteristic feature of a ring of circum-flagellar coccoliths (Figs 28, 29). Rods arise pairwise from neighbouring widened scale rim crystallites. It is evident from Fig. 29 that both the rod and the subtending enlarged crystallite are apically notched to improve contact. One rod protrudes distally as a clawlike structure above the others (Fig. 29). Rods within each pair are differentiated by size (width). Wigwamma antarctica most closely resembles $W$. annulifera. Both species have dimorphic coccoliths, basically identical scale rim calcification, simple body coccoliths with only scale rim calcification, and flagellar pole superstructures that consist of pairs of rods arising from opposite points along the scale periphery where each pair consists of a slender rod and a wing-like lamina (which is little pronounced in $W$. antarctica while profusely developed in $W$. annulifera), and a claw-like anterior projection terminating the superstructure. The claw arises from a wing-like element. The stunning similarity between the flagellar pole coccoliths of W. triradiata and $W$. antarctica must also be emphasized.

\section{W. armatura Thomsen sp. nov.}

Diagnosis: Cells spherical, ca. $5 \mu \mathrm{m}$ in diameter with two flagella and a somewhat shorter haptonema. Cells are devoid of chloroplasts. Cell surface covered by an underlayer of organic scales and coccoliths of two types, i.e. body coccoliths with a simple rim calcification and circum-flagellar coccoliths with an additional superstructure. Organic under layer scales measure $1.0-1.5 \mu \mathrm{m}$ and display fairly regular radiating threads that are crossed by irregular arcs of eccentric fibrils. Oval body coccoliths $(1.8-2.2 \mu \mathrm{m})$ form a complete armour that surrounds the cell at some distance (ca. $1 \mu \mathrm{m}$ ) from the plasmalemma. The rim calcification consists of a ring of rod-shaped crystallites encircling the organic base plate and superimposed on this a ring of larger, rectangular crystallites. The organic base plate displays radiating microfibrils and a pattern of irregular threads crossing these. The superstructure of a circum-flagellar coccolith is composed of four fairly narrow rods (ca. $1.5 \mu \mathrm{m}$ long) that attach to enlarged crystallites from the rim calcification. All rods cross apically to form a cluster of short, projecting claw-like spines.

Ethymology: The specific epithet 'armatura' (L) = 'armour' denotes the protective layer of coccoliths encasing the cell body.

Type specimen: Holotype: Fig. 35.

Type locality: ANT X/3 \# 21/355, Antarctica, Weddell Sea at 7.20 W and 70.22 S. Sampling depth $2 \mathrm{~m}$ and water temperature $-0.6^{\circ} \mathrm{C}$.

Wigwamma armatura resembles W. triradiata (Fig. 17), W. annulifera (Figs 22, 23) and W. antarctica (Fig. 30) with regard to details of body coccolith calcification. Also the flagellar pole coccoliths that occur interspersed among body coccoliths (Figs 35, 37) are 'wigwams' reminiscent of those found in other species of Wigwamma. It is difficult due to the lack of proper three-dimensional images and the frequent dislocation of coccolith elements when cells are dried down on a grid surface, to verify whether rods are equidistantly arranged as in W. arctica (Fig. 4) or grouped in two quasi-opposing

\footnotetext{
Figs 20-25. Wigwamma annulifera TEM (Figs 20-24) and SEM (Fig. 25) whole mounts. 20 - complete cell showing a tuft of flagellar pole coccoliths with winged superstructures and simple oval body coccoliths that vary significantly in size (Antarctica / EPOS); 21 - reversed printing of flagellar pole coccolith showing details of the superstructure and the base plate rim calcification (Arctic Station); 22 - body coccolith (reversed printing) showing very clearly the two-layered scale rim calcification (Antarctica / EPOS); 23 - body coccoliths (reversed printing) with very distinct base plate patterning (Arctic / NEW); 24 - complete cell; notice the marked difference in body coccolith dimensions (Arctic / NEW); 25 - SEM image of complete cell; notice the highly conspicuous flanges on the flagellar pole coccolith superstructures and the size diversification of body coccoliths; some coccoliths at the posterior end carry minute superstructures (Arctic / Svalbard).
} 
Coccolithophorids - Wigwamma revisited 247

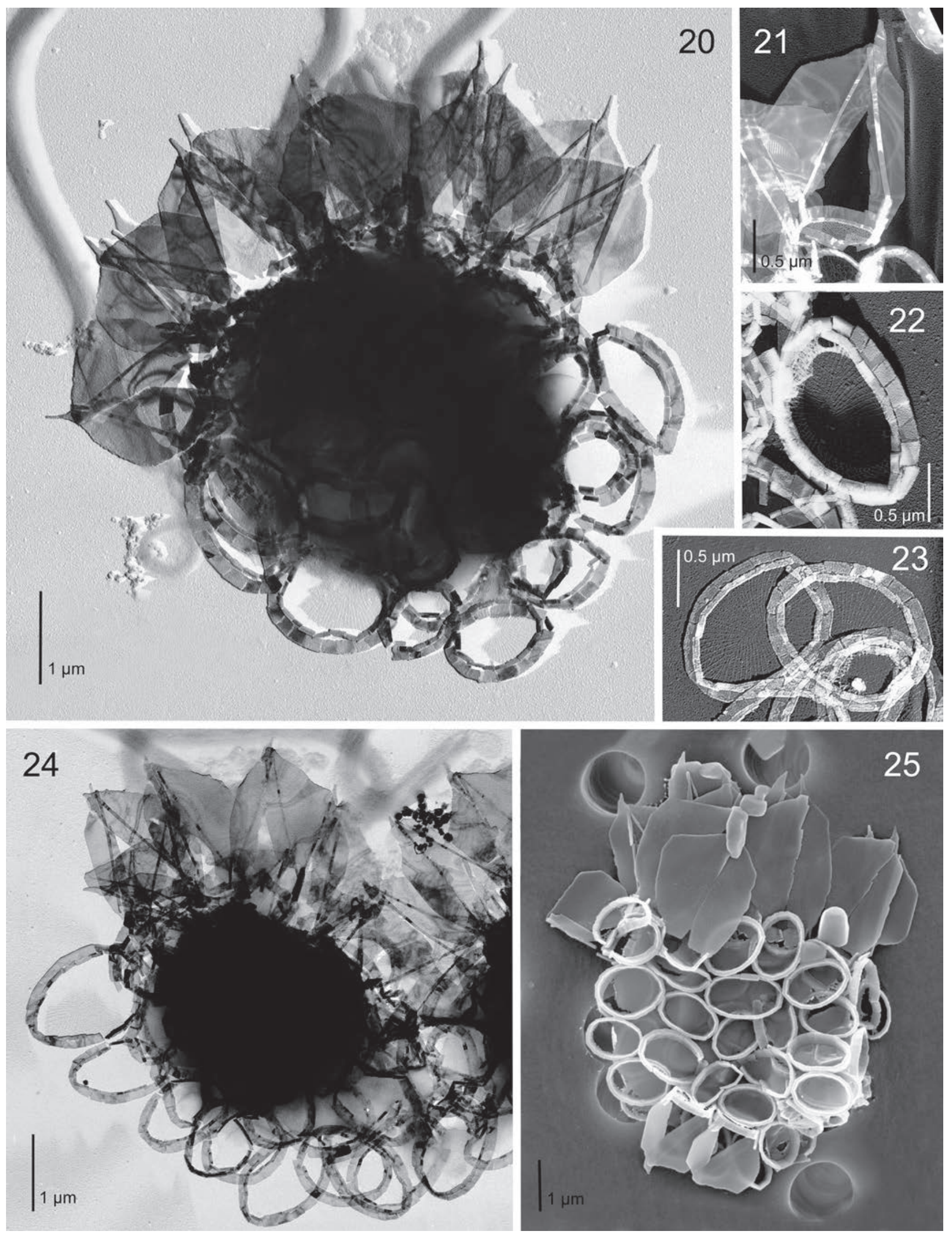




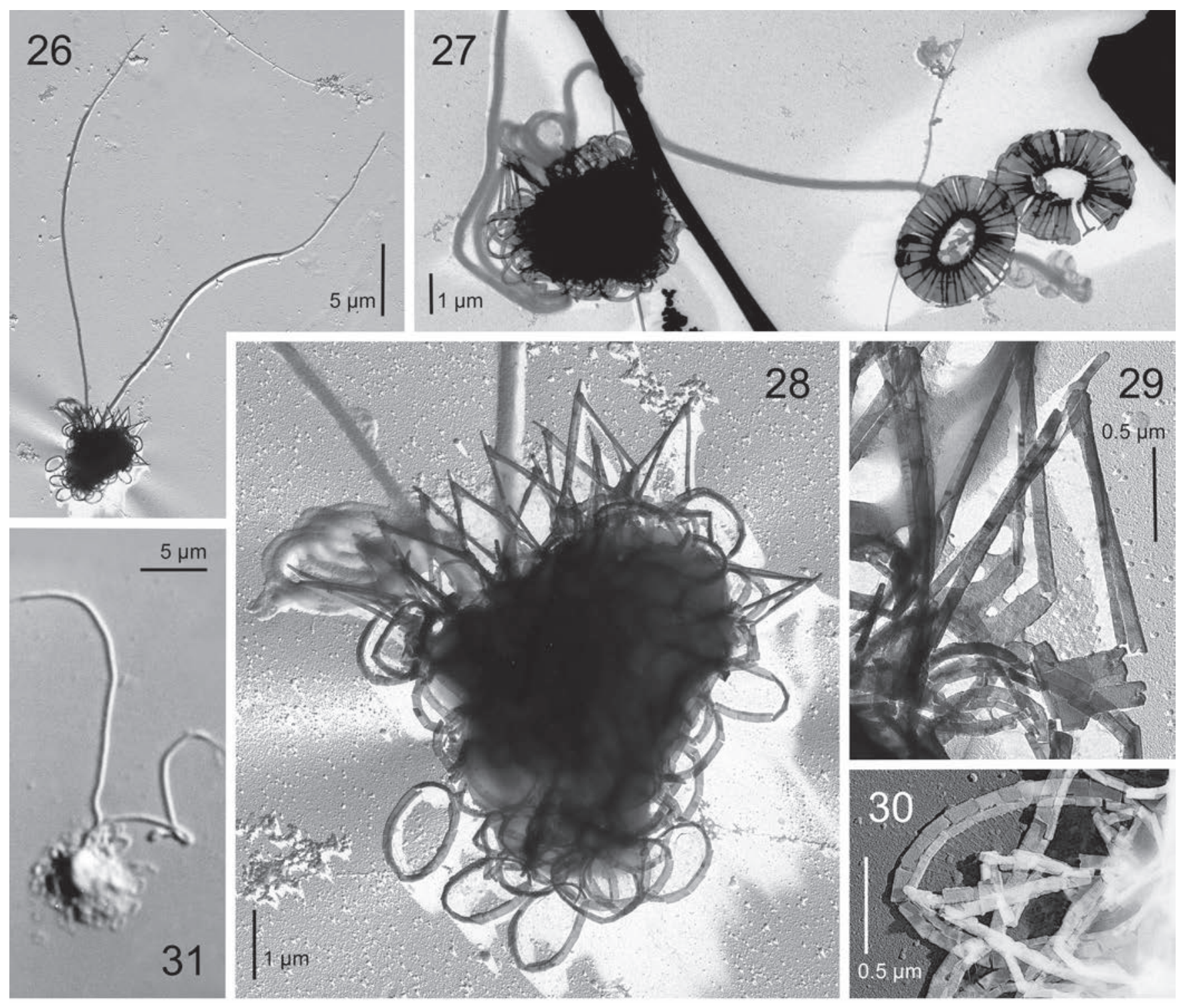

Figs 26-31. Wigwamma antarctica TEM (Figs 26-30) and LM (Fig. 31) whole mounts (Antarctica / EPOS). 26 - complete cell with coiled up haptonema; 27 - complete cell; notice that the entire cell almost equals an Emiliana huxleyi coccolith in overall size; 28 - detail from Fig. 26 showing the two basic types of coccoliths; $\mathbf{2 9}$ - detail of flagellar pole coccolith; notice the protruding finger-like projection of one rod, the notched interlocking between a rod and the subtending enlarged crystallite; $\mathbf{3 0}$ - reversed printing of body coccolith showing scale rim calcification and base plate patterning (radial fibres); 31 - light micrograph (Nomarski contrast) of whole cell.

Figs 32-39. Wigwamma armatura sp. nov. LM (Figs 32-34) and TEM (Figs 35-39) whole mounts (Antarctica /ANT X/3). 32-34 - light micrographs (Nomarski contrast) of the same living cell in different focal planes; notice the absence of a chloroplast and the space between the cell surface and the coccolith periplast; 35 - complete cell (type specimen) with the flagella and haptonema curled up; the periplast is composed of oval body coccoliths of varying sizes and a few interspersed flagellar pole coccoliths with tent-like superstructures; $\mathbf{3 6}$ - detail of flagellar pole coccoliths; 37 - a second complete cell with appendages and coccolith periplast; 38-39 - details of body coccoliths (Fig. 38 reversed printing) showing scale rim calcification, base plate patterning and unmineralized under layer scales. 
Coccolithophorids - Wigwamma revisited 249

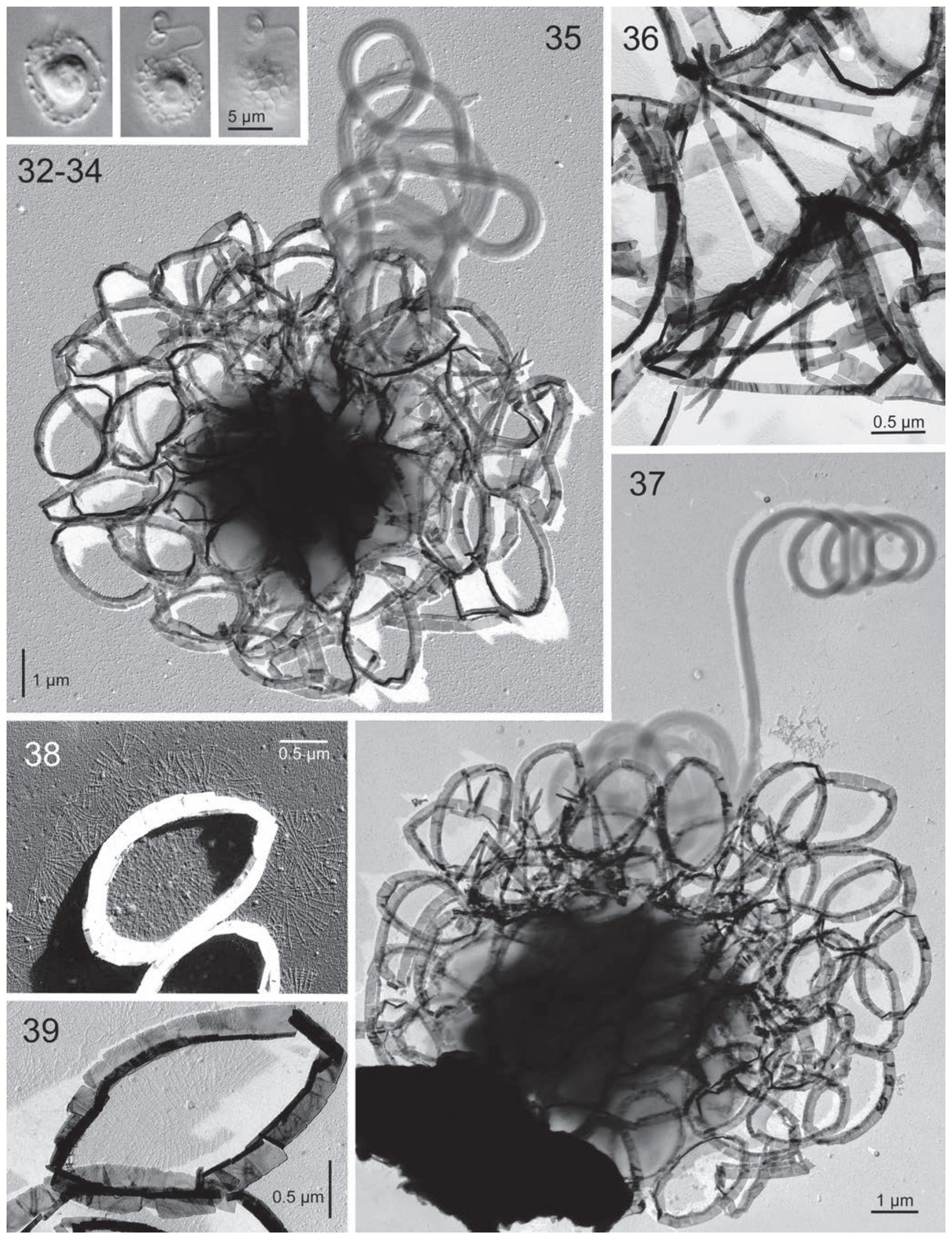


pairs as in W. riradiata, W. annulifera and W. antarctica circum-flagellar coccoliths. However, most evidence (e.g. Fig. 36 showing two superstructures in side view) seems to support that the geometry of W. armatura superstructures is basically similar to that of e.g. W. arctica and characterized by rods that distribute themselves fairly regularly along the scale periphery.

A feature which unequivocally sets $W$. armatura apart from other species of Wigwamma is the highly distinct gap between the cell surface and the coccolith armour (Figs 32-34), a feature which also manifests itself by the voluminous appearance of the coccolith investment compared to the protoplast itself in TEM whole mounts (Figs. 35, 37). The tuft of projecting spines terminating the $W$. armatura superstructure is another unique feature for this taxon.

The description of $W$. armatura is based solely on material from ANT X/3. However, when re-examining material from the AMERIEZ cruise it was evident, that a few somewhat damaged cells of $W$. armatura were also recorded here.

\section{Combination cells involving Wigwamma cfr. body coccoliths}

Thomsen et al. (1991) in a survey of Arctic heteroand holococcolithophorid combination cells with reference in particular to the genera combinations Papposphaera/Turrisphaera and Pappomonas/Trigonaspis also included a single specimen (Thomsen et al. 1991, 1.c. Fig. 18) that simultaneously displayed heterococcoliths highly reminiscent of those found in e.g. W. annulifera and holococcoliths similar to those of Calciarcus alaskensis Manton, Sutherland and Oates (1977). The indirect evidence in favour of combining species of Wigwamma and species of Calciarcus in a common life history is strengthened significantly by finding additional combination cells from West Greenland (Figs 40, 41) and Antarctica (Figs 42-44 / EPOS material).

The only currently known northern hemisphere species of Wigwamma that morphologically matches the rim calcification shown in Figs 40, 41 is W. annulifera. However, the Calciarcus component illustrated in Thomsen et al. (1991, 1.c. Fig. 18) deviates from that shown here (Fig. 40) to an extent that clearly implies that Calciarcus is present in West Greenland waters with more than one species. One possible conclusion to be drawn from this is, despite the immediate similarity of the 'Wigwamma' coccoliths in the two combination cells so far encountered in West Greenland waters, that there must be at least a second, though not yet encoun- tered arctic species, that shares the scale rim calcification signature with $W$. annulifera. The situation is different in the southern hemisphere where three species are at present known to mirror the $W$. annulifera scale rim calcification (W. annulifera, W. antarctica, W. armatura) and thus being candidates to form part of the Wigwamma/Calciarcus life history. However, a counterbalancing diversity with regard to species of Calciarcus has not yet been observed in Antarctic waters (Thomsen and Østergaard in prep.). It is important to emphasize that lessons learned from the study of lifecycle associations within normally calcified coccoliths, e.g. Syracosphaera pulchra and Coronosphaera mediterranea (Geisen et al. 2002) are of course of relevance when evaluating also the Wigwamma-Calciarcus lifecycle associations. In both Syracosphaera pulchra and Coronosphaera mediterranea the heterococcolith phase has been associated with two different holococcolithophorid taxa. Geisen et al. (2002) speculate that cryptic speciation in the heterococcolithophorid phase is the most likely explanation of the phenomenon observed. There is an obvious possible analogy between these well documented cases and Wigwamma/Calciarcus in West Greenland (HET-HOL-HOL).

Taxonomic conclusions at the generic level need at a certain point to materialize in consequence of the highly probable yet only circumstantially documented life history events that combine Wigwamma and Calciarcus. However, it is considered relevant to postpone this formal step until we have a better overall grasp of the Wigwamma and Calciarcus species diversity and the biogeographical ranges of the taxa identified. There are two major prerequisites here. One is the demand for combination cells that display species diagnostic Wigwamma features (i.e. flagellar pole coccoliths) and the other a better understanding of morphological variability and species concepts in Calciarcus spp. It must also in this context be emphasized that there is at present no evidence of a life history linkage between the type species, W. arctica, and any known holococcolithophorid taxon.

\section{Generic circumscription of Wigwamma}

The formal taxonomic diagnosis of Wigwamma (Manton et al. 1977) reads as follows:

Small coccolithophorids with two equal flagella and a short haptonema. Calcification, when present, limited to the rims of otherwise uncalcified plates, some or all rims carrying a superstructure of rod-shaped crystallites converging to a point distally, each rod attached proximally 


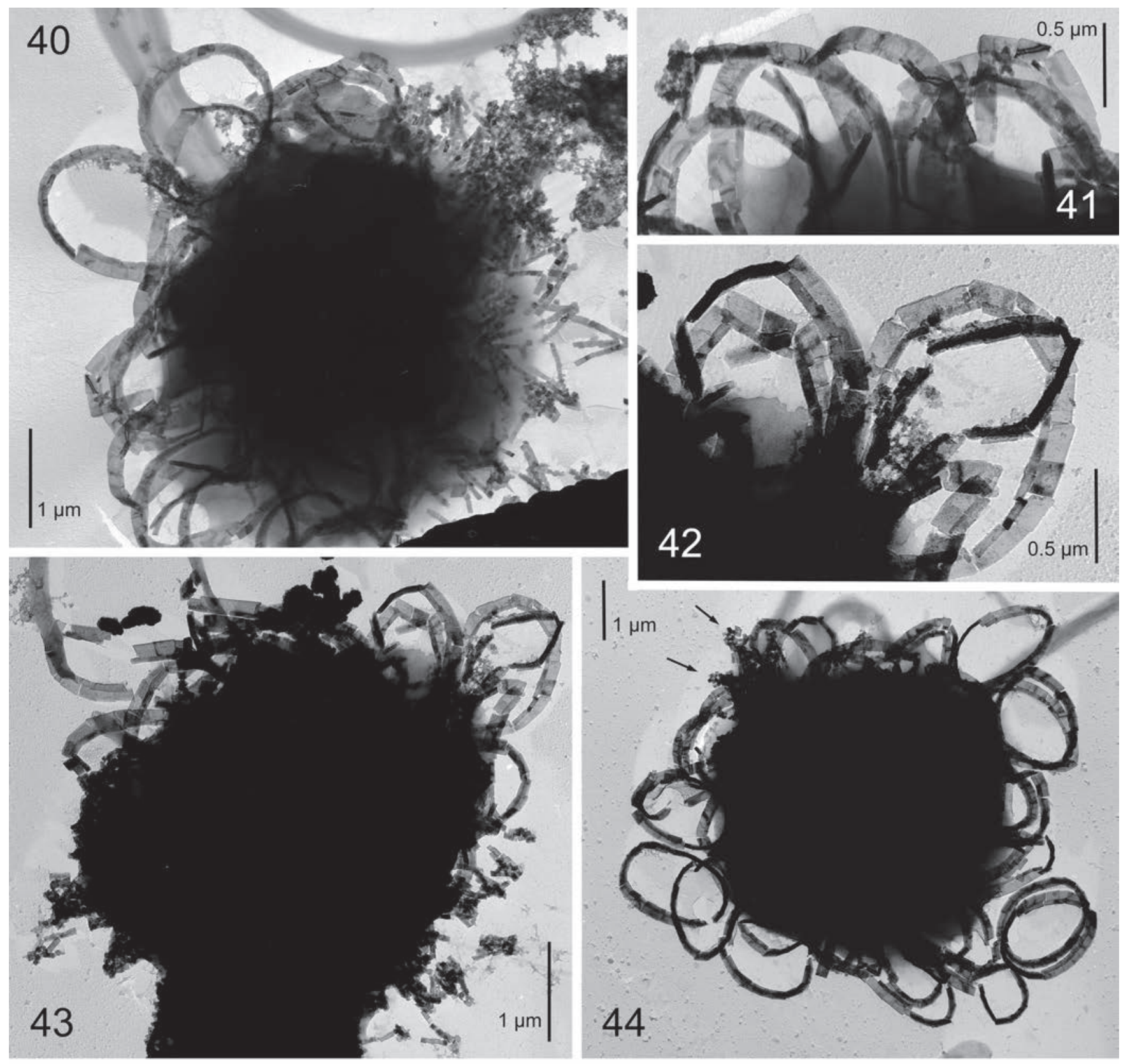

Figs 40-44. Combination cells involving Wigwamma sp. and Calciarcus sp. TEM whole mounts. 40-41 - notice the characteristic pyramidal Calciarcus coccoliths on the right hand side of the cell (Fig. 40), and the simultaneous coverage of Wigwamma cfr. body coccoliths on the left hand side of the cell; for details of scale rim calcification see Fig. 41 (Arctic Station); 42-43 - similar set up with Calciarcus and Wigwamma cfr. coccoliths (see details in Fig. 42) on opposite sides of a protoplast (Antarctica / EPOS); $\mathbf{4 4}$ - yet another cell with the very same basic features; Calciarcus coccoliths are pointed out (Antarctica / EPOS).

to a widened crystallite of the rim; other rim crystallites rectangular, straight sided and joined end to end, arranged in two rows parallel to the subtending plate edge with little other differentiation. Patterning of the unmineralized plate centres apparently composed of threads distributed asymmetrically, some more or less radial but others forming a sparse system of spirals or arcs of circles oriented in relation to one or more focal points not coinciding with the geometrical centre of the scale. Some smaller, rimless unmineralized plates with similar patterning also present. 
When considering the core species of Wigwamma, i.e. W. arctica, W. annulifera, W. antarctica, W. triradiata and $W$. armatura, the original generic description provided by Manton et al. (1977) is robust enough to accommodate all five species. The only point where subsequent analysis of more cells (in casu the type species W. arctica) has documented a larger degree of morphological flexibility is with regard to the attachment between a rod from a superstructure which may occasionally attach to a rim crystallite that is not enlarged or in other ways morphologically differentiated from neighbouring crystallites (e.g. Fig. 5).

\section{Pseudowigwamma Thomsen gen. nov.}

Diagnosis: Small coccolithophorids with two equal flagella and a short haptonema. Calcification, when present, limited to the rims of otherwise uncalcified plates. Rim crystallites rectangular, straight sided and joined end to end to form a single ring. A single enlarged, almost quadratic crystallite is found in most coccoliths. The unmineralized plate centres display a combination of radial threads and concentric fibrils.

Type species: Pseudowigwamma scenozonion (Thomsen 1980c) Thomsen comb. nov.

Ethymology: The genus name Pseudowigwamma meaning 'resembling Wigwamma' is chosen to empha- size a likely relationship with Wigwamma. Pseudowigwamma scenozonion represents - in comparison with Wigwamma - a simplistic approach with regard to coccolith morphology (only one ring of crystallites along the scale periphery and no superstructures).

\section{P. scenozonion (Thomsen 1980c) Thomsen comb. nov.}

Syn. Wigwamma scenozonion Thomsen 1980c

This enigmatic former Wigwamma species is monomorphic (Figs 45-47) and characterized by coccoliths with a much reduced base plate calcification compared to species of Wigwamma. The scale rim calcification here consists of a single ring of rod shaped crystallites as opposed to two rings in species of Wigwamma. A single enlarged crystallite reminiscent of those that support coccolith superstructures in species of Wigwamma is seen in most coccoliths (Figs 46, 47).

The deviant base plate calcification of $P$. scenozonion and the complete lack of a coccolith superstructure was originally (Thomsen 1980c) interpreted as reductional charateristics of this taxon. However, it was also anticipated (Thomsen 1980c) that in the future it might prove relevant to establish a new genus to accommodate this taxon.

Arctic material from NEW yielded a combination cell (Figs 48-49) that encompasses a lightly calci-
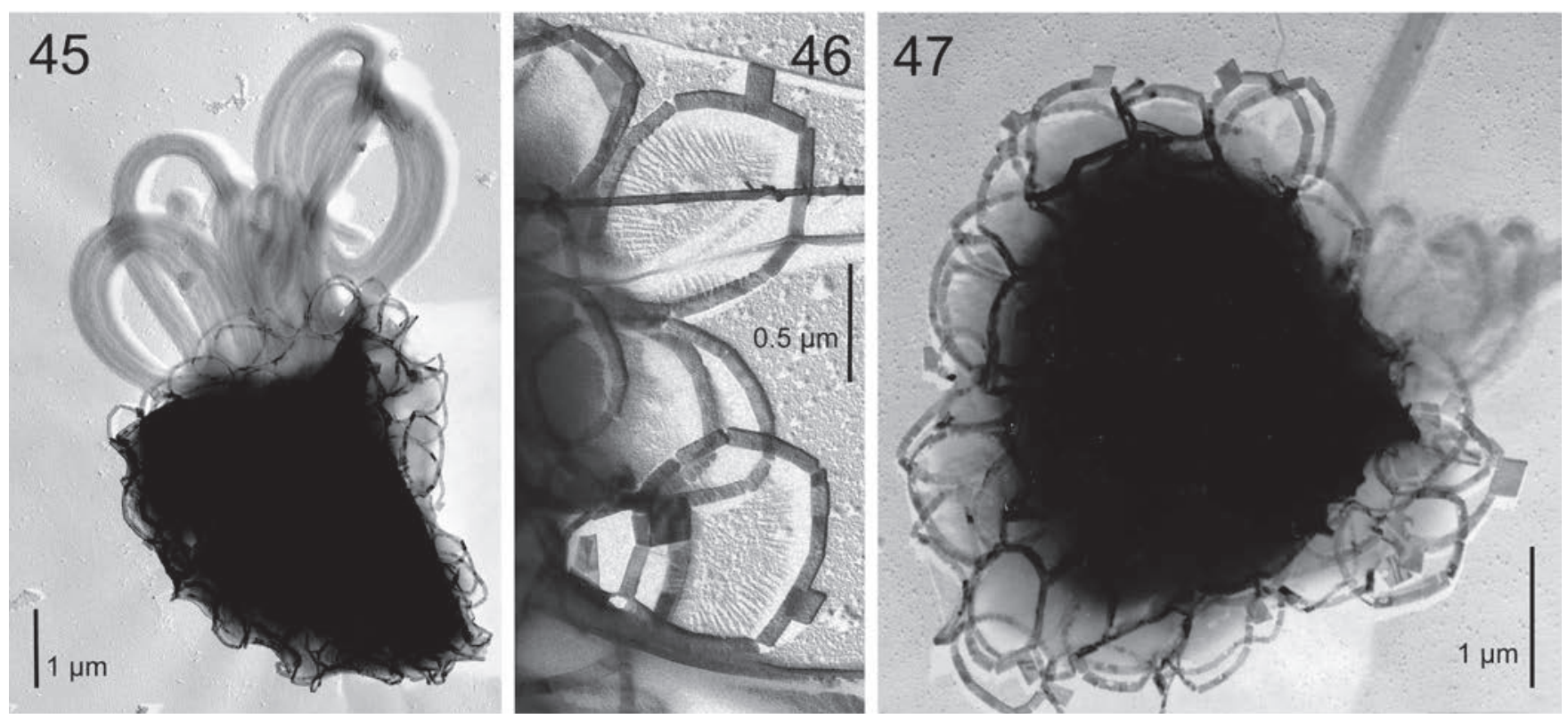

Figs 45-47. Pseudowigwamma scenozonion TEM whole mounts. 45 - complete cell (Arctic / NEW); 46 - detail showing base plate calcification (single layer) and the odd enlarged rim crystallite; Notice also the radial patterning of the organic base plate surface (Arctic Station); 47 - complete cell (Arctic Station). 
fied coccolithophorid species with a rim calcification strongly reminiscent of $P$. scenozonion and an unknown counterpart (also found as a complete cell, see Figs 50 52) with unmineralized scales furnished with a lateral protuberance. Unfortunately none of the calcified coccoliths shown in Fig. 48 display the enlarged crystallite singlet that is a key feature of P. scenozonion (Fig. 46). This leaves an element of uncertainty with regard to the final identification of the calcified component of the combination coccosphere. However, it seemed to be a general feature of $P$. scenozonion from the NEW material that enlarged crystallite singlets were sparse if not absent in some complete specimens analyzed (e.g. Fig. 45). The scaly periplast of the life history counterpart of $P$. scenozonion cfr. comprises apparently unmineralized and weakly rimmed scales furnished with a peripheral protuberance that appear to be aligned along the longitudinal axis of the scale (Figs 50, 52). This type of scale is unknown to us, although vaguely reminiscent of Ericiolus spp. (Thomsen et al. 1995).

Pseudowigwamma scenozonion was considered enigmatic right from its original description (Thomsen 1980c) due to major differences in calcification. The finding of $P$. scenozonion cfr. combination cells which
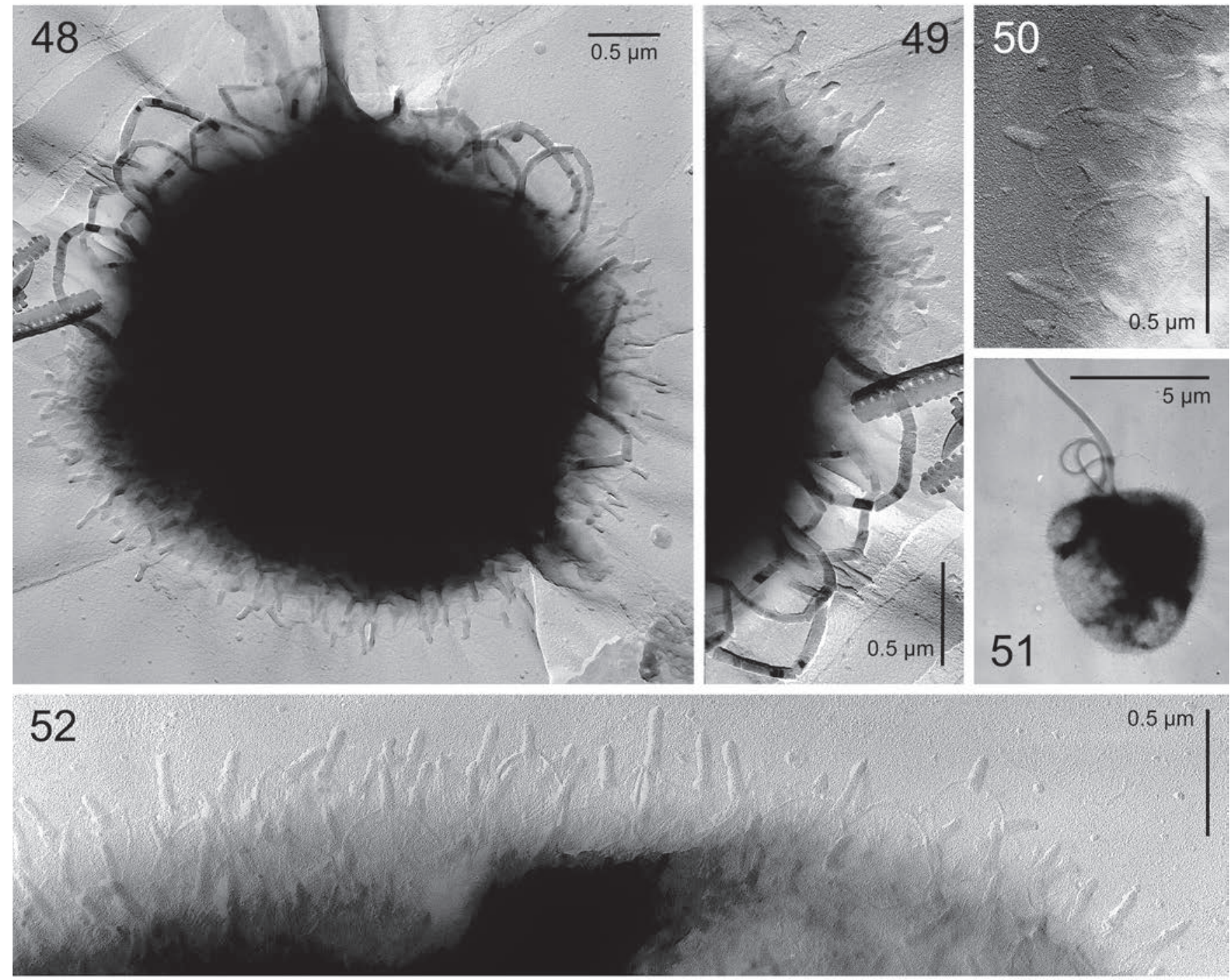

Figs 48-52. Combination cells involving Pseudowigwamma scenozonion cfr. and an unidentified taxon. TEM whole mounts (Arctic / NEW). 48-49 - combination coccosphere; details of the scale types involved are shown in Fig. 49; 50-52 - partly complete cell (one flagellum missing) of the umineralized counterpart; details of the scales are shown in Fig. 50 (reversed printing) and Fig. 52. 
demonstrates that these are not confirming to the "typical' Wigwamma-Calciarcus scenario calls for a formal separation at the generic level between W. scenozonium and the remaining five Wigwamma species.

\section{Biogeography}

The known findings of species of Wigwamma and Pseudowigwamma are tabulated below (Table 2). Two species of Wigwamma, W. arctica and W annulifera, and Pseudowigwamma scenozonion are characteristic elements of the northern high latitude coccolithophorid community, while a handful of Wigwamma species is consistently found to be present in samples processed from the southern high latitudes. A few of the species accounted for here (i.e. W. annulifera, W. arctica and
P. scenozonion) are also reported from significantly lower latitudes, i.e. Danish coastal waters and Cape Town, S. Africa. The recordings of W. arctica and P. scenozonion from Danish coastal waters were associated with a winter inflow of cold $\left(\mathrm{ca} .3^{\circ} \mathrm{C}\right)$ water of presumably North Atlantic origin. Wigwamma annulifera so far stands apart from all other taxa reported here with respect to its temperature tolerances. The temperature at the S. African type locality was ca. $10^{\circ} \mathrm{C}$.

The chance to collect and process over a significant time span nanoplanktonic samples from highly diverse polar regions has unequivocally demonstrated the existence of a persistent polar community of lightly calcified coccolithophorid taxa comprising a range of genera and including e.g. species of Wigwamma and

Table 2. Known geographical distribution of Wigwamma spp. and Pseudowigwamma scenozonion.

\begin{tabular}{|c|c|c|c|c|c|c|c|c|c|c|c|c|c|}
\hline \multirow{2}{*}{$\frac{\text { Region }}{\text { Locality }}$} & \multicolumn{7}{|c|}{ Northern hemisphere } & \multicolumn{6}{|c|}{ Southern hemisphere } \\
\hline & 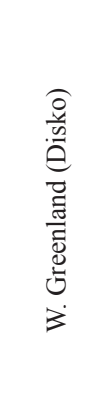 & 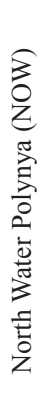 & 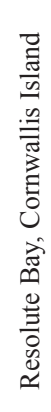 & 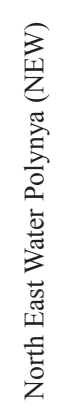 & 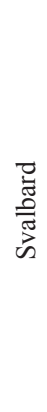 & 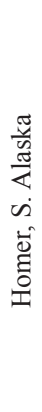 & 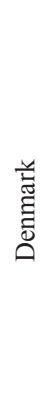 & 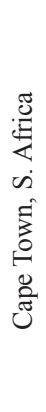 & 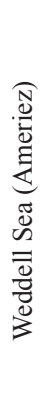 & 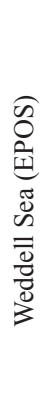 & 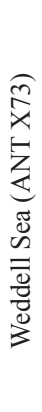 & 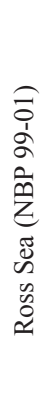 & 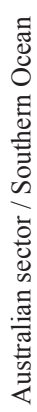 \\
\hline \multicolumn{14}{|l|}{ Wigwamma } \\
\hline W. annulifera & $4,8,9$ & & & 5,11 & 5 & 1 & & 1 & 2 & 5 & 5 & & \\
\hline W. antarctica & & & & & & & & & 2 & 5 & 5 & & 10 \\
\hline W. arctica & $1,4,7,8,9$ & 11 & 1 & 5,11 & & & 3 & & 2 & 5 & 5 & & \\
\hline W. armatura & & & & & & & & & 5 & & 5 & & \\
\hline W. triradiata & & & & & & & & & 2 & 5 & 5 & 11 & 10 \\
\hline \multicolumn{14}{|l|}{ Pseudowigwamma } \\
\hline P. scenozonion & $6,7,8,9$ & & & 11 & & & 3 & & & & & & \\
\hline
\end{tabular}
1) Manton et al. 1977
7) Hansen et al. 1988
2) Thomsen et al. 1988
8) Clausen et al. 1994
3) Thomsen, unpublished data
9) Østergaard 1993
4) Thomsen 1981
10) Findlay and Giradeau 2000
5) This publication
11) Gammelgaard 2000
6) Thomsen 1980 
Pseudowigwamma. The lightly calcified polar coccolithophorids are known to be non-photosynthetic heterotrophs, a feature which must be interpreted as a strong competitive characteristic for organisms that have to survive life in darkness for a period of several months every year. Apart from that very little is known about environmental factors that select for these organisms in high latitude environments while simultaneously virtually blocking other coccolithophorid species.

In a recent paper by Charalampopoulou et al. (2011) analyzing coccolithophorid communities and environmental variables (macronutrients, salinity, temperature, irradiance, $\mathrm{pH}$ and $\Omega_{\text {calcite }}$ ) along a transect from the southern North Sea to the ice-covered marginal ice edge north of Svalbard, a multivariate approach was used to analyze their data. It was shown that most of the variation in coccolithophorid distribution could be explained by variation in $\mathrm{pH}$ and mixed layer depth illumination. A very distinct community characterized by species of Pappomonas and Papposphaera but also encompassing a Wigwamma sp., was found north of Svalbard. The authors found that high $\mathrm{pH}$ values (mean value 8.40) and low temperatures (mean value $-0.9^{\circ} \mathrm{C}$ ) were most likely responsible for this cluster separating markedly from all other coccolithophorid communities identified along the transect studied. It thus appears that the competitive niche successfully occupied by this contingent of weakly calcified coccolithophorid taxa can be markedly threatened in a climate change perspective where increases in sea temperature and a general trend towards lower $\mathrm{pH}$ values will prevail.

Acknowledgements. Thanks are due to crew members and scientific personnel on board all the research cruises that supplied material for this publication. Staff at the Arctic Station, W. Greenland, is acknowledged for granting us access to the station and its facilities on many occasions. We thank Dr. Tove Gabrielsen, the University Centre in Svalbard, for samples from Rijpfjorden and Egil S. Erichsen, Laboratory for Electron Microscopy, University of Bergen for SEM work. Part of the work (Heldal) was financed by the European Research Council Advanced Grant project no. 250254 "MINOS". Finally we want to acknowledge valuable comments to the manuscript received from a reviewer.

\section{REFERENCES}

Andruleit H., Young J. R. (2010) Kataspinifera baumannii: a new genus and species of deep photic coccolithophores resembling the non-calcifying haptophyte Chrysochromulina. J. Micropalaeontology 29: 135-147

Billard C. (1994) Life cycles. In: The Haptophyte Algae (Eds. J. C. Green, B. S. C. Leadbeater). The Systematics Assoc. Special Vol. no. 51. Clarendon Press, Oxford, 167-186
Charalampopoulou A., Poulton A. J., Tyrell T., Lucas M. I. (2011) Irradiance and $\mathrm{pH}$ affect coccolithophore community composition on a transect between the North Sea and the Arctic Ocean. Mar. Ecol. Progr. Ser. 431: 25-43

Clausen S., Gedde D., Grastrup-Hansen D., Levinsen H., Riis T., Vestergaard O. (1994) Hydrografi og plankton i Diskobugt. In: Arktisk Biologisk Feltkursus, Qeqertarqsuaq/Godhavn 1994 (Ed. C. Ehrhardt). Univ. Copenhagen, 83-190

Cros L., Kleijne A., Zeltner A., Billard C., Young J. R. (2000) New examples of holococcolith-heterococcolith combination coccospheres and their implications for coccolithophorid biology. Mar. Micropaleontology 39: 1-34

Findlay C. S., Giraudeau J. (2000) Extant calcareous nannoplankton in the Australian Sector of the Southern Ocean (austral summers 1994 and 1995). Mar. Micropaleontology 40: 417-439

Gammelgaard M. (2000) Marint fytoplankton i åbne polære områder med hovedvægten lagt på skæl- og loricabærende former - kvalitative og kvantitative undersøgelser. Masters thesis. University of Copenhagen, 1-142

Geisen M., Billard C., Broerse A., Cros L., Probert I., Young J. (2002) Life-cycle associations involving pairs of holococcolithophorid species: intraspecific variation or cryptic speciation? Eur. J. Phycol. 37: 531-550

Hansen L. E., Nielsen D., Skovgaard K., Østergaard J. B. (1988) Taxonomiske og kvantitative undersøgelser af de nanoplanktoniske grupper krave- og kalkflagellater i de frie vandmaser ved Disko, Grønland. In: Feltkursus Arktisk Biologi 1988 (Ed. M. Jørgensen). Univ. Copenhagen, 51-142

Houdan A., Billard C., Marie D., Not F., Saez A. G., Young J. R., Probert J. (2004) Holococcolithophore-heterococcolithophore (Haptophyta) life cycles: flow cytometric analysis of relative ploidy levels. Systemat. Biodiv. 4: 453-465

Houdan A., Probert I., Zatylny C., Véron B., Billard C. (2006) Ecology of oceanic coccolithophores. I. Nutritional preferences of the two stages in the life cycle of Coccolithus braarudii and Calcidiscus leptoporus. Aquat. Microb. Ecol. 44: 291-301

Lewis W. M., Jr. (1985) Nutrient scarcity as an evolutionary cause of haploidy. Am. Nat. 125: 692-701

Manton I., Oates K. (1975) Fine-structural observations on Papposphaera Tangen from the southern hemisphere and on Pappomonas gen. nov. from South Africa and Greenland. Br. Phycol. J. 10: 93-109

Manton I., Sutherland J. (1975) Further observations of the genus Pappomonas Manton et Oates with special reference to $P$. virgulosa sp. nov. from West Greenland. Br. Phycol. J. 10: 377-385

Manton I., Sutherland J., McCully M. (1976a) Fine structural observations on coccolithophorids from South Alaska in the genera Papposphaera Tangen and Pappomonas Manton et Oates. $\mathrm{Br}$. Phycol. J. 11: 225-238

Manton I., Sutherland J., Oates K. (1976b) Arctic coccolithophorids: two species of Turrisphaera gen. nov. from West Greenland, Alaska and the Northwest Passage. Proc. Royal Soc. London, Ser. B. Biol. Sci. 194: 179-194

Manton I., Sutherland J., Oates K. (1977) Arctic coccolithophorids: Wigwamma arctica gen. et sp. nov. from Greenland and arctic Canada, W. annulifera sp. nov. form South Africa and S. Alaska. Proc. Royal Soc. London, Ser. B. Biol. Sci. 197: 145-168

Marchant H. J., Thomsen H. A. (1994) Haptophytes in polar waters. In: The Haptophyte Algae (Eds. J. C. Green. B. S. C. Leadbeater). The Systematics Assoc. Special Vol. no. 51. Clarendon Press, Oxford, 209-228 
Moestrup Ø., Thomsen H. A. (1980) Preparation of shadow-cast whole mounts. In: Handbook of Phycological methods. Vol. III. (Ed. E. Gantt). Cambridge 385-390

Nöel M. H., Kawachi M., Inouye I. (2004) Induced dimorphic life cycle of a coccolithophorid, Calyptrosphaera sphaeroidea (Prymnesiophyceae, Haptophyta). J. Phycol. 40: 112-129

Østergaard J. B. (1993) Nanoplanktoniske coccolithophorer (Prymnesiophyceae) og nanoplanktoniske, loricabærende choanoflagellater (Acanthoecidae) i farvandet omkring Godhavn, Grønland. Masters thesis, Univ. Copenhagen

Quintero-Torres R., Aragón J. L., Torres M., Estrada M., Cros L. (2006) Strong far-field coherent scattering of ultraviolet radiation by holococcolithophores. Physical Review E 74: 032901(1-4)

Thomsen H. A. (1980a) Two species of Trigonaspis gen. nov. (Prymnesiophyceae) from West Greenland. Phycologia 19: 218-299

Thomsen H. A. (1980b) Turrispheara polybotrys sp. nov. (Prymnesiophyceae) from West Greenland. J. Mar. Bio. Assoc. U.K. 60: 529-537

Thomsen H. A. (1980c) Wigwamma scenozonion sp. nov. (Prymnesiophyceae) from West Greenland. Br. Phycol. J. 15: 335-342

Thomsen H. A. (1980d) Quaternariella obscura gen. et sp. nov. (Prymnesiophyceae) from West Greenland. Phycologia 19: 260-265

Thomsen H. A. (1981) Identification by electron microscopy of nanoplanktonic coccolithophorids (Prymnesiophyceae) from West Greenland, including the description of Papposphaera sarion sp. nov. Br. Phycol. J. 16: 77-94

Thomsen H. A. (1982) Planktonic choanoflagellates from Disko Bugt, West Greenland, with a survey of the marine nanoplankton of the area. Meddelelser om Grønland, Bioscience 8: 3-35
Thomsen H. A., Buck K. R., Chavez F. P. (1994) Haptophytes as componens of marine phytoplankton. In: The Haptophyte Algae (Eds. J. C. Green, B. S. C. Leadbeater). The Systematics Assoc. Special Vol. no. 51. Clarendon Press, Oxford, 187-208

Thomsen H. A., Buck K. R., Coale S. L., Garrison D. L., Gowing M. M. (1988) Nanoplanktonic coccolithophorids (Prymnesiophyceae, Haptophyceae) from the Weddell Sea, Antarctica. Nord. J. Bot. 8: 419-436

Thomsen H. A., De Place B. P., Højlund L., Olesen J., Pedersen J. B. (1995) Ericiolus gen. et sp. nov. (Prymnesiophyceae), a new coccolithophorid genus from polar and temperate regions. Eur. J. Phycol. 30: 29-34

Thomsen H. A., Østergaard J. B. (2014) Coccolithophorids in polar waters: Calciarcus spp. revisited. Acta Protozool. (in press)

Thomsen H. A., Østergaard J. B., Hansen L. E. (1991) Heteromorphic life histories in Arctic coccolithophorids (Prymnesiophyceae). J. Phycol. 27: 634-642

Valero M., Richerd S., Perrot V., Destombe C. (1992) Evolution of alternation of haploid and diploid phases in life cycles. Trends Ecol. Evol. 7: 25-29

Young J., Geisen M., Cros L., Kleijne A., Sprengel C., Probert I., Østergaard J. B. (2003) A guide to extant coccolithophore taxonomy. J. Nannoplankton Res. Special Issue 1: 1-125

Received on $21^{\text {st }}$ February, 2013; revised on $15^{\text {th }}$ May, 2013; accepted on 24 $4^{\text {th }}$ May, 2013 